\title{
Delivery of gene silencing agents for breast cancer therapy
}

Haifa Shen ${ }^{* 1,2}$, Vivek Mittal ${ }^{2,3}$, Mauro Ferrari ${ }^{1,4}$ and Jenny Chang ${ }^{* 1,5}$

\begin{abstract}
The discovery of RNA interference has opened the door for the development of a new class of cancer therapeutics. Small inhibitory RNA oligos are being designed to specifically suppress expression of proteins that are traditionally considered nondruggable, and microRNAs are being evaluated to exert broad control of gene expression for inhibition of tumor growth. Since most naked molecules are not optimized for in vivo applications, the gene silencing agents need to be packaged into delivery vehicles in order to reach the target tissues as their destinations. Thus, the selection of the right delivery vehicles serves as a crucial step in the development of cancer therapeutics. The current review summarizes the status of gene silencing agents in breast cancer and recent development of candidate cancer drugs in clinical trials. Nanotechnology-based delivery vectors for the formulation and packaging of gene silencing agents are also described.
\end{abstract}

\section{Introduction: challenges in breast cancer treatment}

Breast cancer is the most frequently diagnosed malignancy in women. In 2012, an estimated 229,060 new cases of invasive breast cancer and 39,920 cancer deaths were expected in women in the United States [1]. With the availability of modern diagnostic tools and increased use of adjuvant systemic therapies, significant progress has been made on early stage breast cancer treatment, and consequently the overall survival rates in breast cancer patients. However, only marginal improvements have been achieved in patients with relapsed metastatic cancer, making it an urgent medical need to develop new, effective therapeutics to treat late-stage breast cancer.

\footnotetext{
*Correspondence: hshen@tmhs.org; jcchang@tmhs.org

'Department of Nanomedicine, The Methodist Hospital Research Institute,

Houston, Texas 77030, USA

5The Methodist Cancer Center, Houston, Texas 77030, USA

Full list of author information is available at the end of the article
}

Small molecule inhibitors targeting selected protein kinases and monoclonal antibodies targeting cell-surface receptors have shown promising results in the fight against cancer, including breast cancer, in the past decade. However, the success stories have been limited to only a handful of drug targets. Many of the key cancercausing genes are traditionally considered 'nondruggable' [2], and thus not enough effort has been dedicated to these genes. Moreover, tumor heterogeneity and genetic instability make it unlikely that a single target will suffice for long-term treatment of most solid tumors.

Ever since its discovery [3], RNA interference has been considered to be capable of rapidly and efficiently knocking down the expression of any gene in any cell type, thus opening a door to treat cancer by targeting every cancercausing gene. Recent progress in research in gene silencing agents and their delivery systems has shed light on the potential of these therapeutic agents for cancer treatment.

In this review, we will summarize the current status of development of gene silencing agents as breast cancer therapeutics and describe the enabling systems for effective delivery of such therapeutics.

\section{Gene silencing agents in breast cancer Introduction}

Two classes of gene silencing agents have been the focus of intense study in recent years: small interfering RNA (siRNA) and small non-coding microRNA. The siRNA molecule regulates expression of a specific protein via degradation of the mRNA molecule. It usually demands a perfect match between the siRNA oligo and the corresponding sequence in mRNA (Figure 1). On the other hand, microRNA molecules regulate gene expression via suppression of translation. One microRNA molecule often modulates the expression of a group of genes.

\section{Small inhibitory RNA}

Although originally discovered as long double-stranded RNA molecules, double-stranded siRNA constructs of 30 nucleotides or less have been the default choice to avoid interferon response from longer molecules [4]. Thousands of siRNA-related research articles have since 


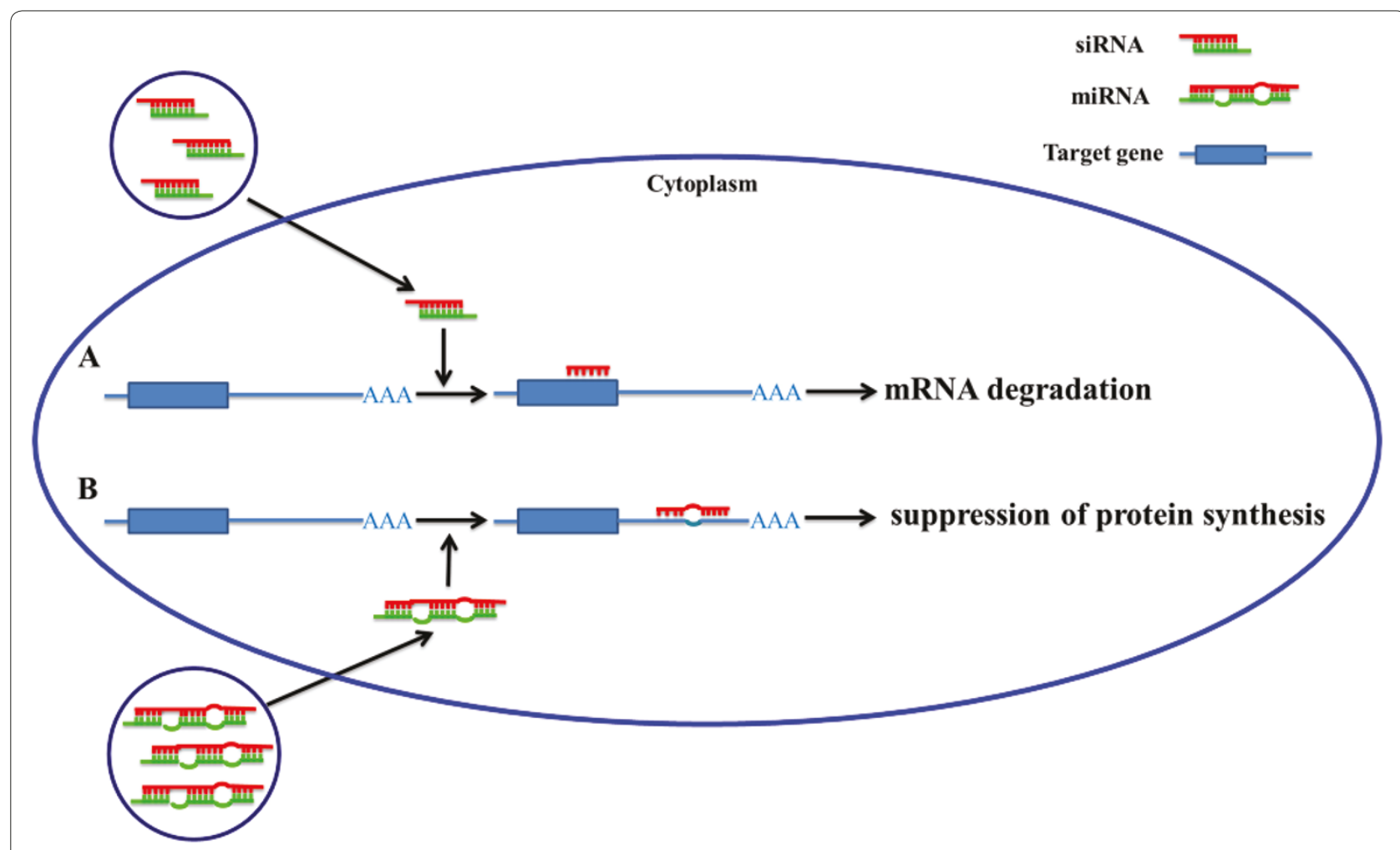

Figure 1. Schematic view of the mechanisms of action of small interfering RNAs (siRNAs) and microRNAs (miRNAs). siRNAs and miRNAs are packaged into nanoparticles for effective delivery. (A) Once inside the cell, the anti-sense strand of the siRNA duplex anneals to the corresponding mRNA molecule (inside or outside of the open-reading frame), and triggers mRNA degradation. (B) On the other hand, the microRNA targets the 3'untranslated region of the mRNA, and suppresses protein synthesis.

been published that demonstrate the essential roles of the individual genes in cell growth and viability. Key cancer genes have also been identified through screening of siRNA/small hairpin RNA (shRNA) libraries for cell proliferation and survival [5]. These genes are involved in almost all the important signal transduction pathways that control tumor initiation, progression, metastasis, and tumor angiogenesis. Detailed information on the individual genes has been published elsewhere, and is not the scope of this article. It has been estimated that there are about 80 mutations in an individual breast tumor, of which a dozen are driving mutations [6]. Adding to the complexity, every cancer patient carries a unique spectrum of gene mutations, making the pool of mutant genes unimaginably large. While the current small molecule cancer drugs can only impact a very small portion of cancer-causing genes, the availability of the specially designed siRNAs targeting the large number of genes makes it possible for personalized treatment of breast cancer based on the genetic and epigenetic changes of every patient.

Genes and pathways that contribute to resistance to current cancer therapy have also been identified.
Trastuzumab has been a key drug to treat Her2-positive breast cancer patients, but not everyone who is positive for Her 2 responds to the treatment. In a large scale RNA interference screening with the Her2-overexpressing BT474 breast cancer cell line, Berns and colleagues [7] discovered that loss of PTEN expression caused resistance to trastuzumab treatment. Since PTEN is a negative regulator of the phosphoinositide 3-kinase (PI3K)/AKT pathway, it is speculated that activation of PI3K signaling confers therapy resistance to trastuzumab. To support this notion, it was found that overexpression of PI3K also caused therapy resistance [7]. Another application of siRNA is to sensitize chemotherapy by knocking down expression of multidrug resistant genes in breast cancer cells. Details will be described in the 'Overcoming therapy resistance' section below.

\section{microRNA}

The microRNAs can be arbitrarily divided into two groups based on their target genes in breast cancer. Table 1 lists microRNAs that play significant roles with known target genes in breast cancer. The group I microRNAs regulate key genes in cancer cell growth and 
Table 1. microRNAs as potential targets for breast cancer therapy

\begin{tabular}{llll}
\hline microRNA & Selected target gene(s) & Function & References \\
\hline let-7 & KRAS, MYC & Tumor growth inhibition & {$[8,47]$} \\
miR-17/20 & CCND1, IL-8 & Regulation of tumor microenvironment & {$[48]$} \\
miR-21 & PTEN/AKT pathway & Tumor progression and metastasis & {$[9]$} \\
miR-103/107 & Dicer & Global microRNA downregulation & {$[10]$} \\
miR-200 family & ZEB1, SIP1 & Epithelial-mesenchymal transition & {$[49]$} \\
miR-205 & HER3, E2F, ZEB1 & Regulation of HER3 expression & {$[11]$} \\
miR-206 & ERa & Suppression of ERa expression & {$[50]$} \\
miR-221/222 & ERa & Tamoxifen resistance by suppression of ERa expression & {$[51]$} \\
miR-708 & NNAT & Inhibition of tumor metastasis & {$[52]$} \\
\hline
\end{tabular}

survival. These include let-7, miR-17/20, miR-21, miR-103/107, the miR-200 family and miR-708, and more members will be identified. One of the first identified microRNAs was let-7. This molecule regulates expression of such important cancer genes as KRAS and MYC [8]. Another example is miR-21, which is overexpressed in breast cancer. It modulates the activity of PI3K/AKT and ERK1/2 pathways via control of PTEN expression. Consequently, treatment of MDA-MB-231 human breast cancer cells with a miR-21 antagomir reversed the oncogenic phenotype of the cell line [9]. In contrast to those described above, miR-103/107 exert their global control of gene expression through modulating dicer expression [10]. Owing to the pivotal role of Dicer in processing and maturation of all non-coding microRNAs, fluctuation of miR-103/107 levels could have a genome-wide impact on gene expression.

Molecules such as miR-205, miR-206, and miR-221/222 represent members of the group II microRNA family. Besides regulating expression of many other genes, members in this group also affect the expression of breast cancer surface markers such as HER3 and ER $\alpha$. For example, miR-205 is one of the regulators of HER3 expression [11]. Interestingly, a recent report revealed that the expression of miR-205 itself was down-regulated by Her2 [12].

It is noteworthy that expression of one specific gene could be controlled by several microRNA molecules. As indicated in Table 1, both the miR-200 family and miR-205 modulate epithelial-mesenchymal transition through regulating $Z E B 1$ expression, and ER $\alpha$ expression is regulated by miR206 and miR-221/222.

\section{Systemic delivery of gene silencing agents for breast cancer therapy \\ Challenges in delivery of therapeutic agents}

Most studies on the biological functions of gene silencing agents have so far been performed using cell-based assays. The excitement and effort in this research field have not been successfully translated into Food and Drug
Administration-approved drugs for treatment of human cancers. The fundamental problem with in vivo application of gene silencing agents is the lack of effective carriers for systemic delivery in order to overcome the multiple biological barriers [13]. Once inside the circulation, the therapeutic agent needs to survive attack from plasma ribonucleases. Without effective protection, most double-stranded RNA oligos will be digested within minutes. They will also need to escape elimination by the reticulo-endothelial system (the sinusoids of the liver, the spleen, and the alveolar beds of the lung). Upon reaching the tumor vasculature, the agents will have to fight against the unfavorable tumor interstitial pressure in order to cross the blood vessel wall. Once inside the tumor tissue, they still need to cross the extracellular matrix and bypass the connective tissues before reaching tumor cells. Since the unmodified double-stranded RNA oligos are negatively charged, they cannot pass the cytoplasmic membrane to reach the cytosol where they act. The default choice to facilitate cell entry of siRNA or microRNA is to package them into cationic nanoparticles. Nanotechnology has played a predominant role in the design of various forms of carriers for in vivo delivery of gene silencing agents so far.

\section{Nanotechnology in breast cancer therapy}

Interestingly, nanotechnology has been used in breast cancer therapy for decades. Doxil, the liposomal formulation of doxorubicin, is the first nano-drug approved for breast cancer therapy; doxorubicin is a potent anticancer drug for breast cancer treatment. However, it tends to accumulate in the heart, thus causing severe cardiac side effects. Nano-formulation of doxorubicin dramatically reduced cardiac side effects [14] while preserving or even enhancing the therapeutic effect of the active drug [15]. Abraxane, the nanoparticle albumin-bound paclitaxel, is another success story of nanotechnology in breast cancer therapy. Paclitaxel has been widely used to treat multiple cancer types, including breast cancer. Traditionally, paclitaxel has been formulated in Cremophor ${ }^{\circledR}$ EL since the 
active drug is hydrophobic. However, this solvent itself can cause severe side effects, such as allergic reactions and neutropenia. Packaging of paclitaxel into the $130 \mathrm{~nm}$ albumin-bound formulation allows for a $50 \%$ increase in drug dosage as a result of decreased overall toxicity compared to the solvent-based formulation [16].

\section{Nanotechnology-based delivery systems for gene silencing agents}

Multiple technology platforms have been developed to deliver gene silencing agents for cancer therapy. The most common approach is to package the double-stranded RNA into nanoparticles that are less than $200 \mathrm{~nm}$ in diameter. This approach takes advantage of the enhanced permeability and retention effect of the leaky tumor vasculature [17]. Since the tumor blood vessel endothelium is disorganized with gaps ranging from 100 to $500 \mathrm{~nm}$ at the cell juncture [18], the nanoparticles can easily cross the fenestration to reach tumor interstitium (Figure 2). Based on the nature of the packaging material, this group of delivery carriers can be divided into lipidbased and non-lipid-based nanovectors. The lipid-based nanovectors include liposomes [19], stable nucleic acid lipid particles (SNALPs) [20], and lipidoid nanoparticles [21]. Non-lipid-based nanovectors contain chitosan [22], poly(amido amine) dendrimers [23], polyethylenimines [24], or other polymeric materials as the building blocks. Conjugates composed of lipid-polymers or polymerpolymers have also been frequently used for siRNA delivery [25]. Another commonly used siRNA carrier is gold nanoparticles. In addition, nanoparticles free of any added materials except the siRNA building block itself have also been reported [26]. Dependent on whether there are targeting moieties on the surface of the particles, these delivery carriers can also be divided into active targeting and passive targeting vectors (Figure 2). A few products that are currently in clinical trial are introduced below.

\section{RNA delivery by passive targeting}

siRNA oligos have taken the lead to reach clinical trials for cancer therapy. Most of the current candidate drugs are formulated into lipid-based nanovectors without active targeting moieties on the surface. Both TKMPLK-1 from Tekmira Pharmaceuticals and ALN-VSP02 from Alnylam Pharmaceuticals use SNALPs as the delivery vector. The SNALPs consist of the ionizable cationic lipid 1,2-dilinoleyloxy-3-dimethylaminopropane (DLinDMA) as the core lipid component. They have a high siRNA encapsulation capacity with a small and uniform size. TKM-PLK-1 consists of a polo-like kinase 1 (PLK1)-specific siRNA packaged in SNALPs. PLK1 is involved in cell cycle progression, and targeted delivery of PLK1 siRNA suppresses growth and metastasis of
Her2+ breast cancer in orthotopic xenograft models [27]. ALN-VSP2 is the first product with dual targeting agents, consisting of siRNA oligos specific to the vascular endothelial growth factor (VEGF) and kinesin spindle protein (KSP) [28]. It is hypothesized that knocking down both genes in the same cancer cells might have an additive or even synergistic effect on cell growth and viability. New cationic lipid molecules have recently been identified to prepare more effective SNALP for siRNA delivery [29]. It is anticipated that more gene silencing products based on SNALP will be developed in the coming years. Since SNALP tends to accumulate in the liver, the main indication of these drugs is to treat liver cancer or liver metastasis of other solid cancers.

Atu027 from Silence Therapeutics is composed of a protein kinase N3 (PKN3)-specific siRNA in positively charged liposomes prepared with a mixture of cationic and fusogenic lipids [30]. PKN3 is a downstream effector of the PI3K pathway, one of the most important pathways in breast cancer biology. Knockdown of PKN3 impairs growth of primary breast and prostate tumor, and blocks tumor metastasis [31]. A phase I trial with advanced solid cancer has been completed with this agent [32].

siRNA-EphA2-DOPC is formulated by mixing the EphA2 siRNA with the neutral lipid 1,2-dioleoyl-snglycero-3-phosphocholine in an excessive amount of $t$ butanol followed by lyophilization [33]. EphA2 encodes the ephrin receptor tyrosine kinase that is overexpressed in multiple cancer types, including breast cancer. Blocking EphA2 activity by antibody-drug conjugates or through knockdown of gene expression inhibits tumor growth [33]. Additionally, dual targeting of EphA2 and other cancer genes has shown enhanced tumor growth inhibition [34]. Although most of the initial studies have been focused on ovarian cancer, the disease indication for the current clinical trial includes all solid tumors [35].

\section{RNA delivery by active targeting}

CALAA-01 from Calando Pharmaceutics is not only the first siRNA therapeutic in a human cancer clinical trial but is also formulated with active targeting [36]. The siRNA specific for the M2 subunit of ribonucleotide reductase (RRM2) is encapsulated in a cyclodextrin nanoparticle. An affinity moiety of the human transferrin protein targeting ligand is decorated on the surface of the nanoparticle. It has been well documented that the transferring receptor protein is overexpressed on the surface of cancer cells, and can be used for effective tumor targeting [37]. The $70 \mathrm{~nm}$ nanoparticles are small enough to cross the fenestration following systemic administration. Once inside the tumor tissue, the targeting moiety would direct the nanoparticle to tumor cells with overexpressed transferring receptor. The first-in-human cancer trial has demonstrated accumulation of RRM2 

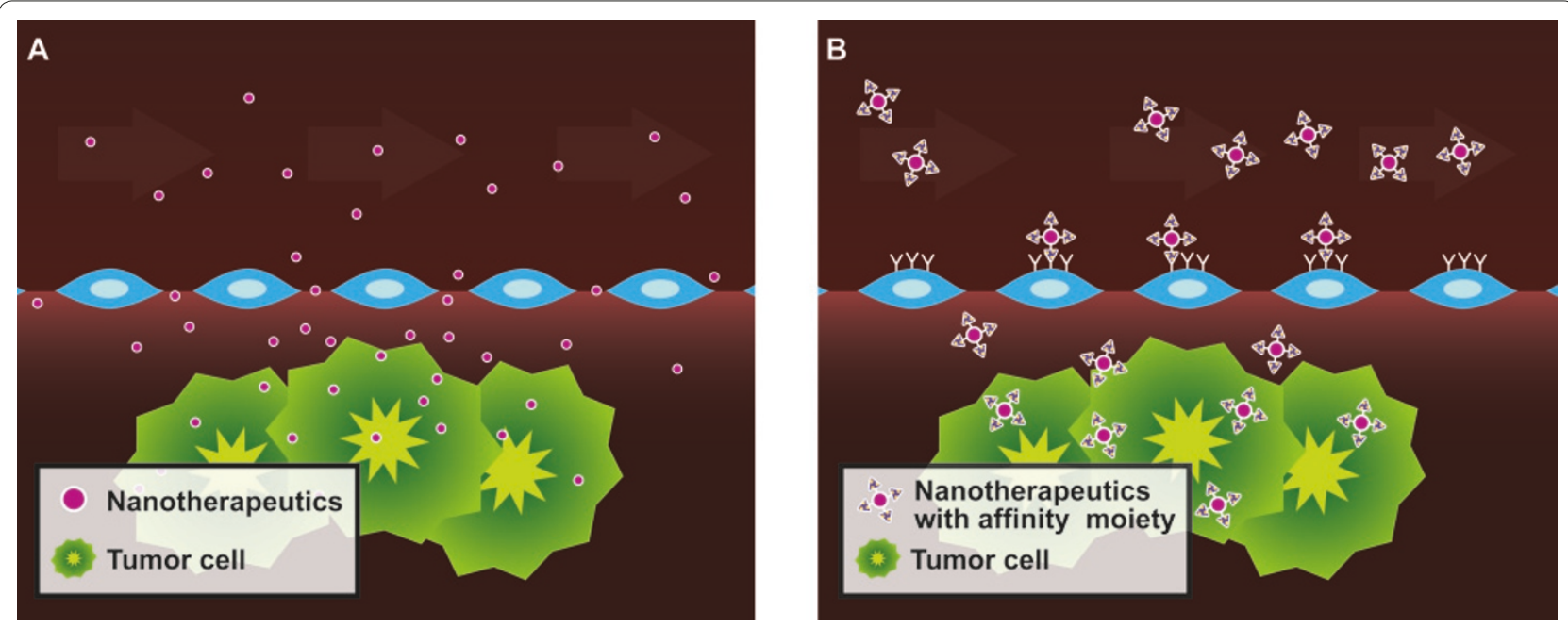

Figure 2. Schematic views of nanoparticle delivery. (A) Nanoparticle delivery by passive targeting. In this mode, nanoparticles pass through the leaky vasculature and enter tumor tissues. (B) Nanoparticle delivery by active targeting. In this mode, the surface of nanoparticles is coated/ conjugated with an active targeting moiety, such as peptide, antibody, or aptamer. Binding of the targeting moiety with cell surface molecules facilities tumor tissue entry of the nanoparticle.

siRNA in tumor tissues and gene-specific knockdown of expression [36]. Although the clinical trial was carried out with melanoma patients, there is no reason to believe that CALAA-01 cannot be used to treat other cancer types such as breast cancer given that RRM2 controls DNA synthesis and damage repair during the cell cycle.

\section{Multistage vector for RNA delivery}

The multistage vector (MSV) delivery system was designed to maximize tumor delivery of therapeutic agents through sequential negotiation with the biological barriers [13]. The system consists of a first stage nanoporous silicon microparticle and a second stage nanoparticle loaded into the nanopores of the first stage particle. For delivery of gene silencing agents, the doublestranded RNA molecules are packaged into 30 to $40 \mathrm{~nm}$ liposomes that are then loaded into the 60 to $80 \mathrm{~nm}$ pores of the porous silicon [38,39]. Once inside the bloodstream, the first stage particles travel with the blood flow and settle at tumor vasculature, where the liposomal siRNAs are released. The pace of siRNA release is determined by the diameter of the nanopore, the size of the liposome, and the rate of silicon degradation.

The first stage microparticles are designed based on size, shape, and surface chemical properties to achieve maximal tumor enrichment. The hemispherical and discoidal particles are more effective in adhesion to tumor vasculature than particles with other shapes such as spherical and cylindrical [40]. The size of the microparticle is a major determinant of particle accumulation. The $1 \mu \mathrm{m}$ discoidal particles accumulate more than the sub-micrometer or the $3.2 \mu \mathrm{m}$ particles with the same shape in melanoma tissues [40]. Interestingly, the size of the particle also affects the efficiency of affinity targeting. Surface conjugation of the RDG targeting moiety significantly enhances tumor accumulation of the submicrometer particles, but has minimum impact once the size exceeds $1 \mu \mathrm{m}$ [40]. Surface chemical modification not only affects protein binding but also determines the loading efficiency of the second stage particles into the nanopores. Since the liposomal siRNA carries a negative Zeta potential, the surface of the nanopores is modified with polyamine to facilitate loading of nanoparticles [41].

This system has been successfully applied to deliver siRNA for cancer treatment with experimental tumor models $[38,39,42]$. Treatment of tumor mice with one dose of MSV/EphA2 siRNA resulted in knockdown of EphA2 expression for up to 3 weeks due to sustained release of liposomal siRNA [39]. It is suspected that the $\mathrm{MSV} / \mathrm{siRNA}$ in tumor vasculature and other organs serves as a depot for constant supply of the gene-silencing agent [43]. In a recent study, $\mathrm{Xu}$ and colleagues [42] treated an orthotopic model of MDA-MB-231 primary tumor with siRNA targeting the $A T M$ gene delivered in the MSV. Effective knockdown of ATM expression resulted in dramatic inhibition of tumor growth. Since efficacy and toxicity constitute the two major aspects of siRNA therapeutics, they also carried out studies to systematically evaluate toxicity that might have been caused by MSV/ATM. After careful evaluation, it was determined that no acute immunotoxicity or sub-acute toxicity was associated with MSV/ATM siRNA, paving the pathway for development of MSV/ATM siRNA as a therapeutic agent for breast cancer [42]. 


\section{Overcoming therapy resistance}

One area of siRNA therapeutics that has shown great promise is sensitization to chemotherapy. Overexpression of multidrug-resistant genes has been attributed to chemoresistance. MacDiarmid and colleagues [44] used a short hairpin RNA to knock down expression of the MDR1 gene in vivo, and subsequently treated murine models of human cancers with chemotherapy drugs. Navarro and colleagues [25] synthesized a DOPE-PEI (dioleoylphosphatidylethanolamine-polyethylenimine) conjugate to enhance transfection capacity of the low molecular weight PEI. They used the conjugate to deliver MDR1-specific siRNA, and demonstrated sensitization to doxorubicin treatment of the otherwise resistant MCF-7 cells. We have recently demonstrated sensitization of docetaxel treatment by EphA2 siRNA in a murine model of human ovarian cancer [38].

Another area that has gained increasing attention in breast cancer therapy is the target of cancer stem cells. These cells are resistant to conventional chemotherapy, and are the lethal seeds for tumor recurrence and local and distant metastasis [45]. By comparing differential expression between the bulk of cancer cells and cancer stem cells, we have identified a group of candidate genes that might be essential for growth and survival of cancer stem cells [46]. Our recent experience with MSV delivery of cancer stem cell gene-specific siRNA oligos has resulted in the development of new breast cancer therapeutics. These agents are expected to play a significant role in the fight against breast cancer.

\section{Conclusion and perspectives}

Gene silencing agents will continue to contribute significantly to breast oncology treatment. Recent advances in RNA interference have resulted in the development of multiple candidate siRNA therapeutics being evaluated in the clinic. Non-coding microRNAs will follow suit to be added to the candidate drug list soon. On the other hand, development of delivery vectors for most solid tumor types has lagged. There are not many options available to deliver siRNA/microRNA to primary breast cancer. It is ever harder to deliver therapeutics to distant organs of breast cancer metastasis, such as the brain and bone. More effort should be spent on the design and development of tissue-specific and tumor type-specific delivery systems for siRNAs and microRNAs.

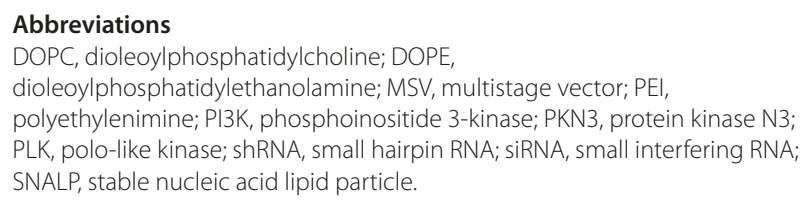

\section{Competing interests}

MF is the founding scientist and a member of the Board of Directors of Leonardo Biosystems, and a member of the Board of Directors of ArrowHead
Research Corporation, and hereby discloses potential financial interests in the companies. The other authors declare that they have no potential conflicts of interest.

\section{Acknowledgements}

The authors acknowledge financial support from the following sources: Department of Defense grants DODW81XWH-09-1-0212 and DODW81XWH-12-1-0414; National Institute of Health grants NIH R01CA128797, NIH R01CA138197, NIH U54CA143837, NIH U54CA149196, NIH U54CA151668; Breast Cancer Research Foundation; Cancer Prevention Research Institute of Texas RP121071; Komen Promise for the Cure KG081694; Golfer's Against Cancer; Team Tiara; Causes for a Cure.

\section{Author details}

'Department of Nanomedicine, The Methodist Hospital Research Institute, Houston, Texas 77030, USA. 2Department of Cell and Developmental Biology, Weill Cornell Medical College, New York, New York 10065, USA. ${ }^{3}$ Department of Cardiothoracic Surgery, Weill Cornell Medical College, New York, New York 10065, USA. Department of Medicine, Weill Cornell Medical College, New York, New York 10065, USA. ${ }^{5}$ The Methodist Cancer Center, Houston, Texas 77030, USA.

Published: 8 May2013

\section{References}

1. Cantley LC, Dalton WS, DuBois RN, Finn OJ, Futreal PA, Golub TR, Hait WN, Lozano G, Maris JM, Nelson WG, Sawyers CL, Schreiber SL, Spitz MR, Steeg PS: AACR Cancer Progress Report 2012. Clin Cancer Res 2012, 18(21 Suppl):S1-100

2. Fauman EB, Rai BK, Huang ES: Structure-based druggability assessment - identifying suitable targets for small molecule therapeutics. Curr Opin Chem Biol 2011, 15:463-468.

3. Fire A, Xu S, Montgomery MK, Kostas SA, Driver SE, Mello CC: Potent and specific genetic interference by double-stranded RNA in Caenorhabditis elegans. Nature 1998, 391:806-811.

4. Elbashir SM, Harborth J, Lendeckel W, Yalcin A, Weber K, Tuschl T: Duplexes of 21-nucleotide RNAs mediate RNA interference in cultured mammalian cells. Nature 2001, 411:494-498.

5. Schlabach MR, Luo J, Solimini NL, Hu G, Xu Q, Li MZ, Zhao Z, Smogorzewska A, Sowa ME, Ang XL, Westbrook TF, Liang AC, Chang K, Hackett JA, Harper JW, Hannon GJ, Elledge SJ: Cancer proliferation gene discovery through functional genomics. Science 2008, 319:620-624.

6. Wood LD, Parsons DW, Jones S, Lin J, Sjöblom T, Leary RJ, Shen D, Boca SM, Barber T, Ptak J, Silliman N, Szabo S, Dezso Z, Ustyanksky V, Nikolskaya T, Nikolsky Y, Karchin R, Wilson PA, Kaminker JS, Zhang Z, Croshaw R, Willis J, Dawson D, Shipitsin M, Willson JK, Sukumar S, Polyak K, Park BH, Pethiyagoda $\mathrm{CL}$, Pant PV, et al: The genomic landscapes of human breast and colorectal cancers. Science 2007, 318:1108-1113.

7. Berns K, Horlings HM, Hennessy BT, Madiredjo M, Hijmans EM, Beelen K, Linn SC, Gonzalez-Angulo AM, Stemke-Hale K, Hauptmann M, Beijersbergen RL, Mills $G B$, van de Vijver MJ, Bernards R: A functional genetic approach identifies the PI3K pathway as a major determinant of trastuzumab resistance in breast cancer. Cancer Cell 2007, 12:395-402.

8. Johnson SM, Grosshans H, Shingara J, Byrom M, Jarvis R, Cheng A, Labourier E, Reinert KL, Brown D, Slack FJ: RAS is regulated by the let-7 microRNA family. Cell 2005, 120:635-647.

9. Han M, Liu M, Wang Y, Chen X, Xu J, Sun Y, Zhao L, Qu H, Fan Y, Wu C: Antagonism of miR-21 reverses epithelial-mesenchymal transition and cancer stem cell phenotype through AKT/ERK1/2 inactivation by targeting PTEN. PLoS One 2012, 7:e39520.

10. Martello G, Rosato A, Ferrari F, Manfrin A, Cordenonsi M, Dupont S, Enzo E, Guzzardo V, Rondina M, Spruce T, Parenti AR, Daidone MG, Bicciato S, Piccolo S: A microRNA targeting dicer for metastasis control. Cell 2010, 141:1195-1207.

11. Iorio MV, Casalini P, Piovan C, Di Leva G, Merlo A, Triulzi T, Menard S, Croce CM, Tagliabue E: microRNA-205 regulates HER3 in human breast cancer. Cancer Res 2009, 69:2195-2200.

12. Adachi R, Horiuchi S, Sakurazawa Y, Hasegawa T, Sato K, Sakamaki T: ErbB2 down-regulates microRNA-205 in breast cancer. Biochem Biophys Res Commun 2011, 411:804-808.

13. Ferrari M: Frontiers in cancer nanomedicine: directing mass transport 
through biological barriers. Trends Biotechnol 2010, 28:181-188.

14. O'Brien ME, Wigler N, Inbar M, Rosso R, Grischke E, Santoro A, Catane R, Kieback DG, Tomczak P, Ackland SP, Orlandi F, Mellars L, Alland L, Tendler C; CAELYX Breast Cancer Study Group: Reduced cardiotoxicity and comparable efficacy in a phase III trial of pegylated liposomal doxorubicin $\mathrm{HCl}$ (CAELYX/Doxil) versus conventional doxorubicin for first-line treatment of metastatic breast cancer. Ann Oncol 2004, 15:440-449.

15. Batist G, Ramakrishnan G, Rao CS, Chandrasekharan A, Gutheil J, Guthrie T, Shah P, Khojasteh A, Nair MK, Hoelzer K, Tkaczuk K, Park YC, Lee LW: Reduced cardiotoxicity and preserved antitumor efficacy of liposome-encapsulated doxorubicin and cyclophosphamide compared with conventional doxorubicin and cyclophosphamide in a randomized, multicenter trial of metastatic breast cancer. J Clin Oncol 2001, 19:1444-1454.

16. Gradishar WJ, Tjulandin S, Davidson N, Shaw H, Desai N, Bhar P, Hawkins M, O'Shaughnessy J: Phase III trial of nanoparticle albumin-bound paclitaxel compared with polyethylated castor oil-based paclitaxel in women with breast cancer. J Clin Oncol 2005, 23:7794-7803.

17. Maeda $\mathrm{H}$ : The enhanced permeability and retention (EPR) effect in tumor vasculature: the key role of tumor-selective macromolecular drug targeting. Adv Enzyme Regul 2001, 41:189-207.

18. Baluk P, Hashizume H, McDonald DM: Cellular abnormalities of blood vessels as targets in cancer. Curr Opin Genet Dev 2005, 15:102-111.

19. Fenske DB, Cullis PR: Liposomal nanomedicines. Expert Opin Drug Deliv 2008, 5:25-44.

20. Zimmermann TS, Lee AC, Akinc A, Bramlage B, Bumcrot D, Fedoruk MN, Harborth J, Heyes JA, Jeffs LB, John M, Judge AD, Lam K, McClintock K, Nechev LV, Palmer LR, Racie T, Röhl I, Seiffert S, Shanmugam S, Sood V, Soutschek J, Toudjarska I, Wheat AJ, Yaworski E, Zedalis W, Koteliansky V, Manoharan M, Vornlocher HP, MacLachlan I: RNAi-mediated gene silencing in non-human primates. Nature 2006, 441:111-114.

21. Akinc A, Zumbuehl A, Goldberg M, Leshchiner ES, Busini V, Hossain N, Bacallado SA, Nguyen DN, Fuller J, Alvarez R, Borodovsky A, Borland T, Constien R, de Fougerolles A, Dorkin JR, Narayanannair Jayaprakash K, Jayaraman M, John M, Koteliansky V, Manoharan M, Nechev L, Qin J, Racie T, Raitcheva D, Rajeev KG, Sah DW, Soutschek J, Toudjarska I, Vornlocher HP, Zimmermann TS, et al: A combinatorial library of lipid-like materials for delivery of RNAi therapeutics. Nat Biotechnol 2008, 26:561-569.

22. Kim HS, Han HD, Armaiz-Pena GN, Stone RL, Nam EJ, Lee JW, Shahzad MM, Nick AM, Lee SJ, Roh JW, Nishimura M, Mangala LS, Bottsford-Miller J, Gallick GE, Lopez-Berestein G, Sood AK: Functional roles of Src and Fgr in ovarian carcinoma. Clin Cancer Res 2011, 17:1713-1721.

23. Monteagudo S, Perez-Martinez FC, Perez-Carrion MD, Guerra J, Merino S, Sanchez-Verdu MP, Cena V: Inhibition of p42 MAPK using a nonviral vectordelivered siRNA potentiates the antitumor effect of metformin in prostate cancer cells. Nanomedicine (Lond) 2011, 7:493-506.

24. Cubillos-Ruiz JR, Engle X, Scarlett UK, Martinez D, Barber A, Elgueta R, Wang L, Nesbeth Y, Durant Y, Gewirtz AT, Sentman CL, Kedl R, Conejo-Garcia JR: Polyethylenimine-based siRNA nanocomplexes reprogram tumorassociated dendritic cells via TLR5 to elicit therapeutic antitumor immunity. J Clin Invest 2009, 119:2231-2244.

25. Navarro G, Sawant RR, Biswas S, Essex S, Tros de llarduya C, Torchilin VP: P-glycoprotein silencing with siRNA delivered by DOPE-modified PEI overcomes doxorubicin resistance in breast cancer cells. Nanomedicine (Lond) 2012, 7:65-78.

26. Lee JB, Hong J, Bonner DK, Poon Z, Hammond PT: Self-assembled RNA interference microsponges for efficient siRNA delivery. Nat Mater 2012, 11:316-322.

27. Yao YD, Sun TM, Huang SY, Dou S, Lin L, Chen JN, Ruan JB, Mao CQ, Yu FY, Zeng MS, Zang JY, Liu Q, Su FX, Zhang P, Lieberman J, Wang J, Song E. Targeted delivery of PLK1-siRNA by ScFv suppresses Her2+ breast cancer growth and metastasis. Sci Trans/ Med 2012, 4:130ra148.

28. Judge AD, Robbins M, Tavakoli I, Levi J, Hu L, Fronda A, Ambegia E, McClintock K, MacLachlan I: Confirming the RNAi-mediated mechanism of action of siRNA-based cancer therapeutics in mice. J Clin Invest 2009, 119:661-673.

29. Semple SC, Akinc A, Chen J, Sandhu AP, Mui BL, Cho CK, Sah DW, Stebbing D, Crosley EJ, Yaworski E, Hafez IM, Dorkin JR, Qin J, Lam K, Rajeev KG, Wong KF, Jeffs LB, Nechev L, Eisenhardt ML, Jayaraman M, Kazem M, Maier MA, Srinivasulu M, Weinstein MJ, Chen Q, Alvarez R, Barros SA, De S, Klimuk SK, Borland T, Kosovrasti V, et al: Rational design of cationic lipids for siRNA delivery. Nat Biotechnol 2010, 28:172-176.

30. Santel A, Aleku M, Keil O, Endruschat J EscheV, Fisch G, Dames S, Löffler K,
Fechtner M, Arnold W, Giese K, Klippel A, Kaufmann J: A novel siRNA-lipoplex technology for RNA interference in the mouse vascular endothelium. Gene Ther 2006, 13:1222-1234.

31. Unsal-Kacmaz K, Ragunathan S, Rosfjord E, Dann S, Upeslacis E, Grillo M, Hernandez R, Mack F, Klippel A: The interaction of PKN3 with RhoC promotes malignant growth. Mol Oncol 2012, 6:284-298.

32. ClinicalTrials.gov: Study With Atu027 in Patients With Advanced Solid Cancer [http://www.clinicaltrials.gov/ct2/show/ NCT00938574?term=atu027\&rank=1]

33. Landen CN Jr, Chavez-Reyes A, Bucana C, Schmandt R, Deavers MT, Lopez-Berestein G, Sood AK: Therapeutic EphA2 gene targeting in vivo using neutral liposomal small interfering RNA delivery. Cancer Res 2005, 65:6910-6918

34. Shahzad MM, Lu C, Lee JW, Stone RL, Mitra R, Mangala LS, Lu Y, Baggerly KA, Danes CG, Nick AM, Halder J, Kim HS, Vivas-Mejia P, Landen CN, LopezBerestein G, Coleman RL, Sood AK: Dual targeting of EphA2 and FAK in ovarian carcinoma. Cancer Biol Ther 2009, 8:1027-1034

35. ClinicalTrials.gov: EphA2 Gene Targeting Using Neutral Liposomal Small Interfering RNA Delivery [http://www.clinicaltrials.gov/ct2/show/ NCT01591356?term=EphA2\&rank=1]

36. Davis ME, Zuckerman JE, Choi CH, Seligson D, Tolcher A, Alabi CA, Yen Y, Heidel JD, Ribas A: Evidence of RNAi in humans from systemically administered siRNA via targeted nanoparticles. Nature 2010, 464:1067-1070.

37. Bellocq NC, Pun SH, Jensen GS, Davis ME: Transferrin-containing, cyclodextrin polymer-based particles for tumor-targeted gene delivery. Bioconjug Chem 2003, 14:1122-1132.

38. Shen H, Rodriguez-Aguayo C, Xu R, Gonzalez-Villasana V, Mai J, Huang Y, Zhang G, Guo X, Bai L, Qin G, Deng X, Li Q, Erm DR, Aslan B, Liu X, Sakamoto J, Chavez-Reyes A, Han HD, Sood AK, Ferrari M, Lopez-Berestein G: Enhancing chemotherapy response with sustained EphA2 silencing using multistage vector delivery. Clin Cancer Res 2013, 19:1806-1815.

39. Tanaka T, Mangala LS, Vivas-Mejia PE, Nieves-Alicea R, Mann AP, Mora E, Han HD, Shahzad MM, Liu X, Bhavane R, Gu J, Fakhoury JR, Chiappini C, Lu C, Matsuo K, Godin B, Stone RL, Nick AM, Lopez-Berestein G, Sood AK, Ferrari M: Sustained small interfering RNA delivery by mesoporous silicon particles. Cancer Res 2010, 70:3687-3696.

40. van de Ven AL, Kim P, Haley O, Fakhoury JR, Adriani G, Schmulen J, Moloney P, Hussain F, Ferrari M, Liu X, Yun SH, Decuzzi P: Rapid tumoritropic accumulation of systemically injected plateloid particles and their biodistribution. J Control Release 2011, 158:148-155.

41. Godin B, Tasciotti E, Liu X, Serda RE, Ferrari M: Multistage nanovectors: from concept to novel imaging contrast agents and therapeutics. Acc Chem Res 2011, 44:979-989.

42. Xu R, Huang Y, Mai J, Zhang G, Guo X, Xia X, Koay EJ, Qin G, Erm DR, Li Q, Liu X, Ferrari M, Shen H: Multistage vectored siRNA targeting ataxiatelangiectasia mutated for breast cancer therapy. Small 2013 [Epub ahead of print].

43. Ferrari M: Vectoring siRNA therapeutics into the clinic. Nat Rev Clin Oncol 2010, 7:485-486

44. MacDiarmid JA, Amaro-Mugridge NB, Madrid-Weiss J, Sedliarou I, Wetzel S, Kochar K, Brahmbhatt VN, Phillips L, Pattison ST, Petti C, Stillman B, Graham $\mathrm{RM}$, Brahmbhatt $\mathrm{H}$ : Sequential treatment of drug-resistant tumors with targeted minicells containing siRNA or a cytotoxic drug. Nat Biotechnol 2009, 27:643-651.

45. Li X, Lewis MT, Huang J, Gutierrez C, Osborne CK, Wu MF, Hilsenbeck SG, Pavlick A, Zhang X, Chamness GC, Wong H, Rosen J, Chang JC: Intrinsic resistance of tumorigenic breast cancer cells to chemotherapy. J Nat/ Cancer Inst 2008, 100:672-679.

46. Dave B, Landis MD, Dobrolecki LE, Wu MF, Zhang X, Westbrook TF, Hilsenbeck SG, Liu D, Lewis MT, Tweardy DJ, Chang JC: Selective small molecule Stat3 inhibitor reduces breast cancer tumor-initiating cells and improves recurrence free survival in a human-xenograft model. PLoS One 2012, 7:e30207.

47. Sampson VB, Rong NH, Han J, Yang Q, Aris V, Soteropoulos P, Petrelli NJ, Dunn SP, Krueger LJ: MicroRNA let-7a down-regulates MYC and reverts MYCinduced growth in Burkitt lymphoma cells. Cancer Res 2007, 67:9762-9770.

48. Yu Z, Willmarth NE, Zhou J, Katiyar S, Wang M, Liu Y, McCue PA, Quong AA, Lisanti MP, Pestell RG: microRNA 17/20 inhibits cellular invasion and tumor metastasis in breast cancer by heterotypic signaling. Proc Natl Acad Sci US A 2010, 107:8231-8236. 
49. Gregory PA, Bert AG, Paterson EL, Barry SC, Tsykin A, Farshid G, Vadas MA, Khew-Goodall Y, Goodall GJ: The miR-200 family and miR-205 regulate epithelial to mesenchymal transition by targeting ZEB1 and SIP1. Nat Cell Bio/ 2008, 10:593-601.

50. Adams BD, Furneaux H, White BA: The micro-ribonucleic acid (miRNA) miR-206 targets the human estrogen receptor-alpha (ERalpha) and represses ERalpha messenger RNA and protein expression in breast cancer cell lines. Mol Endocrinol 2007, 21:1132-1147.

51. Di Leva G, Gasparini P, Piovan C, Ngankeu A, Garofalo M, Taccioli C, lorio MV, Li M, Volinia S, Alder H, Nakamura T, Nuovo G, Liu Y, Nephew KP, Croce CM: MicroRNA cluster 221-222 and estrogen receptor alpha interactions in breast cancer. J Natl Cancer Inst 2010, 102:706-721.
52. Ryu S, McDonnell K, Choi H, Gao D, Hahn M, Joshi N, Park SM, Catena R, Do Y, Brazin J, Vahdat LT, Silver RB, Mittal V: Suppression of miRNA-708 by polycomb group promotes metastases by calcium-induced cell migration. Cancer Cell 2013, 23:63-76.

doi:10.1186/bcr3413

Cite this article as: Shen $\mathrm{H}$, et al.: Delivery of gene silencing agents for breast cancer therapy. Breast Cancer Research 2013, 15:205. 
siRNA \#典

miRNA 표료표표

Target gene

mRNA degradation

B

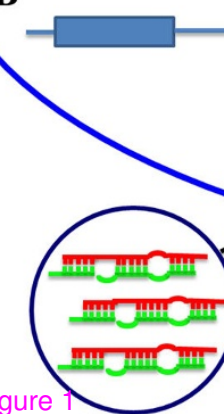

min

suppression of protein synthesis

Figure 


\section{A}

\section{$\circ$}

o

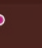

0

0

o

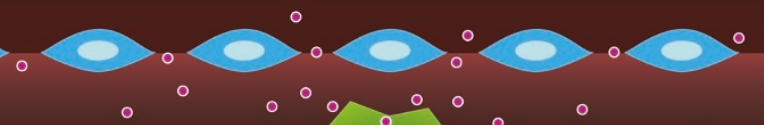

O

○ 0 rencents

\section{Tumor cell}

B

踏 .

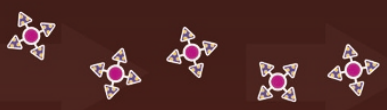

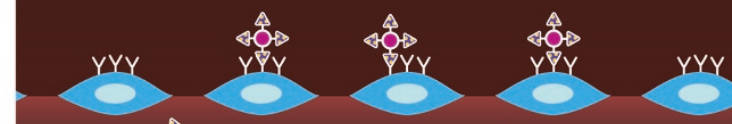

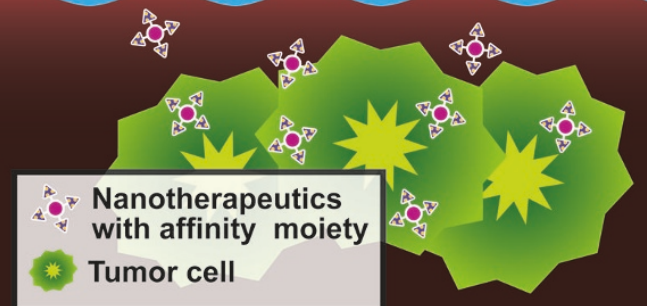

